\title{
Analysis of granulation systems using idealistic modeling-principle of similarity for scaling up sustainable production lines
}

\section{Análisis de sistemas de granulación utilizando modelado idealista-principio de similitud para el escalamiento de líneas productivas sostenibles}

\author{
SALGADO-LOYO, Eduardo $†$, CRUZ-GÓMEZ, Marco Antonio*, TEUTLI-LEÓN, Margarita and \\ MEJÍA-PÉREZ, José Alfredo
}

\begin{abstract}
Benemérita Universidad Autónoma de Puebla; Facultad de Ingeniería, Grupo de Tribología and Transporte, Cuerpo Académico 189 (Prevención de Desastres and Desarrollo Sustentable, Tribología, BUAP), Edificio de Posgrado, Primer nivel, Cubículo Núm. 16, Blvd. Valsequillo esq. Av. San Claudio, Ciudad Universitaria, Col. San Manuel, CP. 72570, Puebla México
\end{abstract}

ID $1^{\text {st }}$ Author: Eduardo, Salgado-Loyo / ORC ID: 0000-0001-5418-4907, Researcher ID Thomson: AAP-2962-2020, CVU CONACYT ID: 1019384

ID $1^{\text {st }}$ Coauthor: Marco Antonio, Cruz-Gómez / ORC ID: 0000-0003-1091-8133, Researcher ID Thomson: S-3098-2018, CVU CONACYT ID: 349626

ID $2^{\text {nd }}$ Coauthor: Margarita, Teutli-León / ORC ID: 0000-0002-8799-8891, Researcher ID Thomson: AAL-8481-2021, CVU CONACYT ID: 120326

ID $3^{\text {rd }}$ Coauthor: José Alfredo, Mejía-Pérez / ORC ID: 0000-0002-4090-8828, Researcher ID Thomson: G-3354-2019

DOI: $10.35429 / J O I E .2021 .16 .5 .1 .7$

Received March 27, 2021; Accepted June 30, 2021.

\begin{abstract}
Pharmaceutical industry produces safe, effective, affordable, and quality medicines used to guarantee a healthy life and promote the well-being of the entire population in a sustainable way. Currently, the solid dosage form is the preferred formulation for human use. However, the large scale production of these medicines it requires well-tested formulation and appropriate equipment because any substantial variation in the development of the pharmaceutical product can alter the final quality of the product, causing the entire manufactured batch to be discarded. For this reason, this research aimed to analyze and understand the behavior of the variables involved in the wet granulation process while scaling from a laboratory system and a production line unit to transfer the results obtained to a large-scale production unit of solid dosage forms to meet the health needs of the world population. This study was carried out under a mixed approach applying quantitative and qualitative technologies to explain and predict the behavior of the involved variables while scaling from a laboratory system to a production line unit. It was found that there are some regularities and causal relationships between geometric, kinematic, and dynamic similarities.
\end{abstract}

Solid dosage form, Scaling, Similarity

\section{Resumen}

El sector farmacéutico produce medicamentos seguros, eficaces, asequibles y de calidad con el fin de garantizar una vida sana y promover el bienestar de toda la población de manera sostenible. Actualmente, la forma de dosificación sólida es la formulación preferida para el uso humano. Sin embargo, la producción de estos medicamentos a gran escala requiere de fórmulas y equipos bien probados, debido a que cualquier variación sustancial en el desarrollo del producto farmacéutico puede alterar la calidad final de este provocando que se deseche todo el lote fabricado. Por tal motivo, esta investigación tuvo como objetivo analizar y entender el comportamiento de las variables implicadas en el proceso de granulación húmeda durante el escalamiento entre un sistema de laboratorio y una unidad de línea de producción con el fin de trasladar los resultados obtenidos a una unidad de producción de formas de dosificación sólidas a gran escala para cubrir las necesidades sanitarias de la población mundial. Este estudio fue realizado bajo un enfoque mixto aplicando tecnologías cuantitativas y cualitativas para explicar y predecir el comportamiento de las variables implicadas durante el escalamiento de dos sistemas al encontrar regularidades y relaciones causales entre las similitudes de tipo geométrica, cinemática y dinámica.

Forma de dosificación sólida, Escalamiento, Similitud

Citation: SALGADO-LOYO, Eduardo, CRUZ-GÓMEZ, Marco Antonio, TEUTLI-LEÓN, Margarita and MEJÍA-PÉREZ, José Alfredo. Analysis of granulation systems using idealistic modeling-principle of similarity for scaling up sustainable production lines. Journal of Innovative Engineering. 2021. 5-16: 1-7

*Correspondence to Author (e-mail: mangcruz@live.com)

$\dagger$ Researcher contributing as first Author. 


\section{Introduction}

The pharmaceutical sector invests 130,000 million euros (per year) in Research and Development "R\&D" to produce safe, effective, affordable, and quality medicines to guarantee a healthy life and promote the well-being of the entire population in a way sustainable. The World Health Organization (WHO) in its Statistics Report of 2020, covering the period between 2000 and 2016, mentions that highlights on life expectancy had increased of $21 \%$ in developing countries and $4 \%$ in more developed countries, fact which is related to access to universal health services covering prevention and/or treatment of diseases.

Therefore, medicines must be available with certified quality assurance to meet the health needs of the population. Fernández, C. (2019), Organización Mundial de la Salud [OMS]. (2020) and Quiroga, R. (2020).

Currently, the solid dosage form (eitablets, capsules, powders, granules, tablets, etc.) is the most explored and preferred formulation for human use. However, the large scale production of these medicines requires well-tested and documented formulation and equipment, because any substantial variation in the development of the pharmaceutical product can alter the final quality of the product, causing the entire manufactured batch to be discarded.

Therefore, the manufacture of oral dosage forms on a large scale is unreasonable without first conducting small-scale experiments. The scale-up process consists of transferring a controlled process from one scale to another. That is, the use of this method implies that the small-scale process is understood and controlled to quickly obtain the optimization and control of the larger-scale process. Faure, A., York, P., \& Rowe, R. C. (2001) and Raval, N., Tambe, V., Maheshwari, R., Deb, P. K., \& Tekade, R. K. (2018).

This research aimed to analyze and understand the behavior of variables involved in the wet granulation process while scaling from a laboratory system to a production line unit, transferring the obtained results from a lab unit to a unit of large-scale production of solid dosage forms.

\section{Methodology}

This study was of a mixed type because quantitative and qualitative approaches were used applied to a set of systematic, critical, and empirical scale-up processes. On the one hand, the quantitative approach was used to collect data regarding pharmaceutical manufacturing (on a large scale) in an objective, sequential and probative way of investigation. Also, it was of vital importance to do a review of scale-up studies based on pharmaceutical granulation, since from this review can be formulated a hypothesis based on deductive reasoning.

Furthermore, use of quantitative studies was necessary to explain and predict the phenomena involved in the development of large-scale pharmaceutical products producing a theory based on finding regularities and causal relationships between scale-up techniques, formulations, machinery, and processes. For this reason, the data generated are valid and the derived conclusions will contribute to knowledge generation. On the other hand, the qualitative approach, based on logic and inductive method, it was required to develop questions and hypotheses, either before, during, or after data collection from different manufacturing methods of solid dosage forms. In addition, this approach was necessary to discover and identify the proper scale-up method for two pellet-making machines. Hernández, R., Fernández, C., \& Baptista, P. (2010).

\section{Large-scale manufacturing}

pharmaceutical

Traditionally in the pharmaceutical industry, the manufacture of solid dosage forms works in batches, because this set-up allows input of a certain amount of input material to be processed through several step operations (for example, reaction, crystallization, filtration, drying, mixing, granulating, tableting, etc.) to finally obtain drug products. Su, Q. et al. (2019).

Wet granulation is a commonly used process in the pharmaceutical industry because this method provides better control on drug dispersion through the solid matrix, especially at low drug concentrations; also, it allows control of apparent density in the final product. 
On the other hand, high-shear granulation is one of the most widely used wet agglomeration techniques in the pharmaceutical industry, because this technique ensures drug distribution as it prevents powder segregation. This technique uses an impeller that keeps stirring powder in a closed bowl while a binder solution is sprayed from the top of the bowl to form the first nuclei of future granules. Faure, A., York, P., \& Rowe, R. C. (2001) and Thapa, P., Tripathi, J., \& Jeong, S. H. (2019).

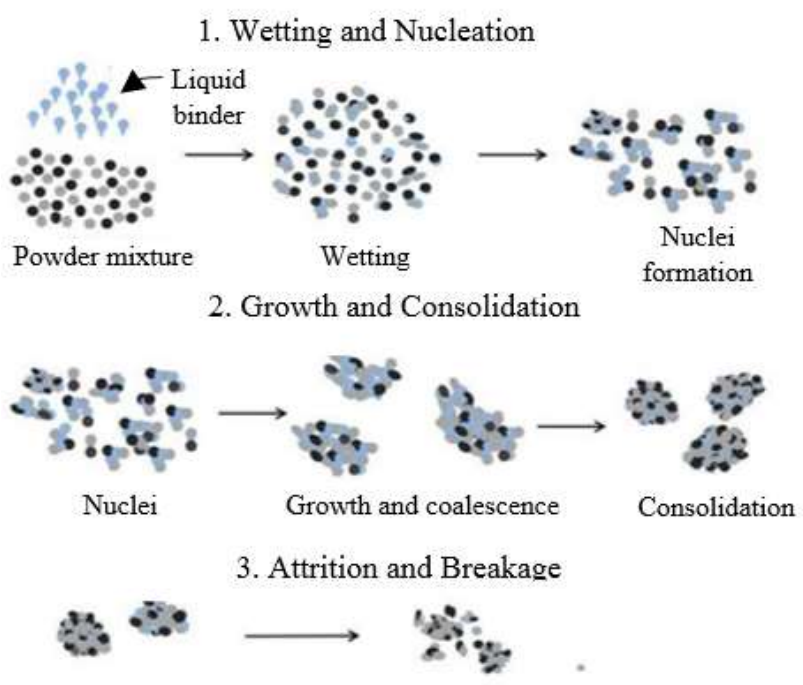

Figure 1 Stages of the wet granulation process. Thapa, P. et al. (2019)

Generally, a limited amount of the drug is available in the initial phase of wet granulation. For this reason, small production equipment should be selected to manufacture small batches. Leuenberger, H., \& Betz, G. (2007). However, at a later stage, the batch size used for large-scale manufacturing will be up to 100 times larger. Therefore, for the large-scale pharmaceutical product to achieve similar characteristics to the small-scale one, it is necessary to employ a good approach in the scale-up process. Raval, N. et al. (2018).

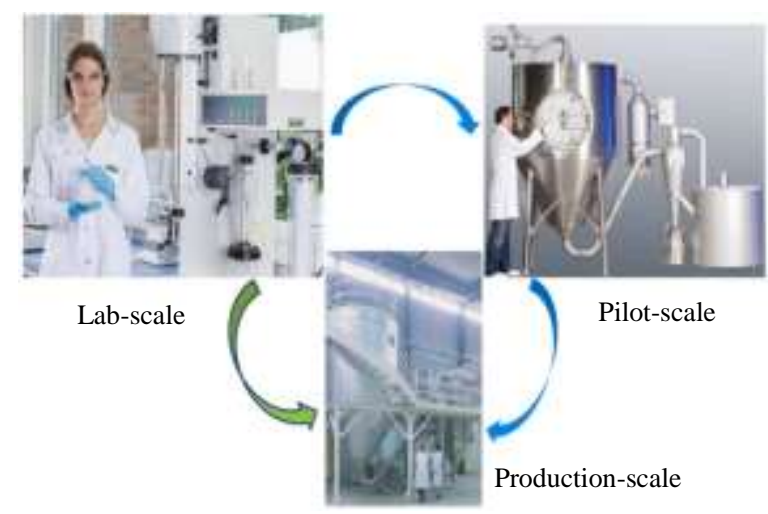

Figure 2 The scale-up process between equipment. Poozesh, S. \& Bilgili, E. (2019)
However, the quality of the granules may vary during this process because any change in compactability, friability, compressibility, final moisture content, and size distribution of the granules can affect the properties of the final tablet. Similarly, the huge amount of models in equipment used for the development of solid dosage forms, usually it complicates scaling between units. Therefore, the formulation of the drug product must be robust, so the final product has the same quality using small and large-scale equipment. Leuenberger, H., \& Betz, G. (2007).

The scale-up process consists of transferring the parameters obtained in a smallscale experiment to a model process. The procedure can be approached through a similarity analysis, phenomenological concepts (based on microscopic theoretical reasoning), or empirical observations (postulated without theoretical bases). Therefore, the scaling model approach depends on the process and the geometry of the equipment involved in the process. Anaya, A. \& Pedroza, H. (2008).

\section{Similarity principle}

Understanding the principle of similarity is essential for the correct application of the scaleup process in two given systems. This principle consists of three types of similarity (geometric, kinematic, and dynamic). On the one hand, two systems are geometrically similar when the relationship between the linear dimensions of the small-scale and scaled-up systems are constant. Leuenberger, H., \& Betz, G. (2007).

In the same way, this type of similarity considers that two solid bodies are composed of three imaginary axes $(x, y, z)$ in the space that intersect them so that all their points are in the same coordinate system. In other words, two bodies are geometrically similar when for every point in the first body there is a point in the second one. Anaya, A. \& Pedroza, H. (2008). On the other hand, two systems of different sizes are kinematically similar when (in addition to the systems being geometrically similar) the velocity relationship between the corresponding points in the two systems are equal. Finally, two systems of different sizes are dynamically similar when (in addition to the systems being geometrically and kinematically similar) the relationship of forces between the corresponding points in the two systems are similar. Leuenberger, H., \& Betz, G. (2007). 


\subsection{Similarity criteria for the wet granulation process}

There are two general methods to satisfying the similarity criteria. The first considers the equations that govern the behavior of the system can be transformed into dimensionless forms. The second is dimensional analysis, an approach derived when the equations that govern the system are unknown, this last allows simplifying the study of any phenomenon in which physical quantities are involved, it is based on Buckingham's theorem.

This consists of changing the dimensional input parameters of a physical problem for another set of smaller dimensionless input parameters to more easily analyze a given system and reduce the number of tests that must be carried out to know the behavior of this system. Anaya, A. \& Pedroza, H. (2008) and Leuenberger, H., \& Betz, G. (2007).

For the wet granulation process, dimensionless groups must be determined from a dimensional analysis because the scale-up method for this process cannot be efficiently defined by mathematical equations relating the control variables. Leuenberger, H., \& Betz, G. (2007) and Raval, N. et al. (2018). For this reason, assuming an ideal behavior for the granulation process which is using a high-speed mixer.

This behavior must consider that the interacting particles are fully fluidized and have similar physical properties, also, there are not long-range particle-particle interactions, plus the air is the dispersion medium therefore its viscosity can be neglected. Based on these considerations, the following dimensionless groups can be identified (according to Buckingham's theorem):

$$
\begin{aligned}
\pi_{1} & =\frac{P}{r^{5} \omega^{3} \rho} \\
\pi_{2} & =\frac{q t}{V \rho} \\
\pi_{3} & =\frac{V}{V^{*}} \\
\pi_{4} & =\frac{r \omega^{2}}{g} \\
\pi_{5} & =\frac{r}{d}
\end{aligned}
$$

where $\pi_{1}$ is the power number, $\pi_{2}$ is the specific amount of the granulation liquid, $\pi_{3}$ is the particle-charged volume fraction, $\pi_{4}$ is the Froude number, $\pi_{5}$ is the geometric number, $\omega$ the angular velocity $\left(\mathrm{rad}-\mathrm{s}^{-1}\right), r$ the radius of the rotating blade (first characteristic length of the mixer in meters), $V$ the volume loaded with particles $\left(\mathrm{m}^{3}\right), V^{*}$ the total volume of the vessel (mixer unit in $\mathrm{m}^{3}$ ), $d$ the diameter of the vessel (second characteristic length of the mixer in meters), $q$ the mass of granulating liquid added per unit time $\left(k g-s^{-1}\right), \rho$ the specific density of the particles $\left(\mathrm{kg}-\mathrm{m}^{-3}\right), P$ is the power consumption (W), $g$ the gravitational acceleration $\left(m-s^{-2}\right)$, and $t$ the process time (s). Leuenberger, H., \& Betz, G. (2007).

\section{Scale-up process in two pharmaceutical units preserving the principle of similarity}

In a study reported by Vercruysse, J. et al. (2015), it is evaluated the predictability of the scaling for the wet granulation and drying processes for a pharmaceutical formulation. The process was analyzed at two levels the ConsiGma 25 "CG25" industrial production line unit and ConsiGma 1 "CG1" laboratory system unit. This formulation consisted of two premixed active pharmaceutical ingredients, powdered cellulose, cornstarch, pregelatinized starch, sodium starch glycolate, and distilled water as granulating liquid.

The CG1 laboratory system consists of a high-shear twin-screw granulation module and a single cell fluidized bed dryer. For the first module of this system, the torque on the screws and the temperature of the cylinder wall were recorded in 1-second intervals, the positive displacement machine with a heated chamber (jacket temperature) of the barrel was set at $25^{\circ}$ $\mathrm{C}$ and screw speed at $900 \mathrm{rpm}$. For the CG1 drying module, the drying time, fill time, powder feed rate, inlet air temperature, humidity, and flow rate were set at $820 \mathrm{~s}, 180 \mathrm{~s}, 20 \mathrm{~kg}-\mathrm{h}^{-1}$, $45^{\circ} \mathrm{C}, 10 \%$ y $80 \mathrm{~m}^{3}-h^{-1}$, respectively. Finally, for testing repeatability of the system, the experiments were performed by triplicate.

The CG25 unit consists of three modules: the first (high-shear wet granulation) has a highshear co-rotating twin-screw agglomeration unit. To evaluate the process in this module, the granulation parameters were transferred directly from CG1 to CG25 because the granulation unit of both systems has the same dimensions.

SALGADO-LOYO, Eduardo, CRUZ-GÓMEZ, Marco Antonio, TEUTLI-LEÓN, Margarita and MEJÍA-PÉREZ, José Alfredo. Analysis of granulation systems using idealistic modeling-principle of similarity for scaling up sustainable production lines. Journal of Innovative Engineering. 2021 
For the second module (six-segment fluidized bed dryer), the same process adjustment parameters used in CG1 were used, because the drying cell of this has the same design as a segment of the CG25 dryer. However, the airflow was set at $420 \mathrm{~m}^{3}-h^{-1}$ to reach adequate fluidization of the wet granules within all the segments of this module. In the third module (granule conditioning), each package of dry granules was collected separately. Finally, short single-cell runs were made by triplicate ( 3 minutes corresponding to 1 $\mathrm{kg}$ of material per run) where only one segment of the CG25 dryer was filled to test the repeatability of the system.

To evaluate the granulation process in both units, the values of torque and temperature of the cylinder wall were analyzed. In the case of the one-hour execution in CG25, the rate of torque variation was not constant, and it decreased as a function of the processing time, going from an increase of $1.5 \mathrm{Nm}$ during the first 20 minutes of the execution to a value of $0.5 \mathrm{Nm}$ during the last 30 minutes of the run. Similarly, a similar trend was detected for the torque in the cylinder wall temperature, going from 23.6 to $29.5^{\circ} \mathrm{C}$ during the first 30 minutes of the run to an increase of 29.5 at $30^{\circ} \mathrm{C}$ for the second part of the run.

However, short runs of a single cell by triplicate showed similar trends in the process data between the different runs. Therefore, data demonstrated high repeatability of the granulation process. For the experiments done on CG1, the torque achieved a plateau phase comparable to the short runs performed on CG25. After the granulation process, the wet agglomerates were transported directly to the drying module of each unit. The CG25 system features a Pt100 temperature sensor in each cell of the six-segment fluid bed dryer that allowed the collection of temperature data.

On the one hand, the temperature profiles obtained during the one-hour run of CG25 and CG1 were comparable. Also, these units registered a temperature of $35^{\circ} \mathrm{C}$ at the discharge of the cells. On the other hand, the granules processed during the CG25 single-cell runs had a slightly higher temperature $\left(37.8^{\circ} \mathrm{C}\right)$ at the discharge from the cell.
This is due to the design of the CG25 dryer because segmentation of this module in six identical dryer cells favors that heat from the surrounding empty cells results transferred (by convection and conduction) to the granule-filled drying cell. Vercruysse, J., Peeters, E., Fonteyne, M., Cappuyns, P., Delaet, U., Van Assche, I., De Beer, T., Remon, J. \& Vervaet, C. (2015).

\section{Results}

The behavior of the variables involved in the wet granulation process strongly depends on the design of the machine used. For this reason, the generation of dimensionless groups for this process allowed understanding the behavior of these variables when scaling a laboratory system to a production line unit. In the same way, the similarity analysis of geometric, kinematic, and dynamic parameters was fundamental to understand the scaling process between two units.

For the granulation process in the CG25 unit, it was detected that a stabilization period was needed for the torque and the temperature of the cylinder wall during the one-hour run. Therefore, slightly deviation in granule quality attributes were observed during the first half of the one-hour run. However, the granule properties of the CG25 single cell tests were comparable to the results obtained during the second half of the one-hour test for the same unit. Also, the processing of the material in a single CG25 drying cell was repeatable in the CG1 unit. Furthermore, quality attributes of the granules processed in a single cell were useful in predicting the ones for the steady-state phase during larger-scale manufacturing despite the slight increase in temperature at the discharge from the cell. Vercruysse, J. et al. (2015).

\section{Discussion of results}

The scale-up experiments carried out between a laboratory system and a production line unit would allow the correct expansion of any process for equipment a thousand times larger than the laboratory unit. For the wet granulation process, the dimensionless groups generated (based on Buckingham's theorem) are of great help to set-up control of the variables involved in this process. However, these groups were generated in an ideal environment. 
For this reason, the principle of similarity would be the indicated method to scale two units, because the analysis and understanding of the three types of similarities of this principle provide intrinsic relations of measures, forces, or transfer rates within each system. Anaya, A. \& Pedroza, H. (2008).

The scale-up of the granulation and drying process between the CG1 and CG25 units showed that the properties of the granules were comparable between both units using the same variables set-up during these processes. However, airflow velocity was the only parameter that did not transfer directly from CG1 to CG25 due to the dryer design of both units. However, the temperature profiles obtained during the one-hour run of CG25 and CG1 were comparable when registering a temperature of $35^{\circ} \mathrm{C}$ at the discharge of the cells. Therefore, the variables of this process could be used for sizing equipment that is geometrically, kinematically, and dynamically like any of the units used in this experiment to produce up to a thousand times more oral dosage forms than the laboratory unit.

However, it is recommended that the design of the large-scale production machine be geometrically similar to the CG25 unit because all the granulation and drying parameters could be transferred causing fewer errors and consequently material losses. Currently, the lack of innovation and technology for the large-scale production of essential medicines has led to shortages of these. For example, the COVID-19 pandemic has caused a substantial excess of mortality during the 2020 and part of the 2021 year due to the lack of supply of vaccines to combat this disease.

Consequently, the urgent need to manufacture and increase the supply of this medicine has produced new methods of development and large-scale production. However, increasing production to meet global demand is a great challenge because only a few countries have the technological capacity to produce this medicine on a large scale. In early March 2021, the scientific analysis company Airfinity highlighted that China is a world leader in the production of COVID-19 vaccines with a total of $141,624,000$ vaccines. This production is because Chinese pharmaceutical companies have had a constant growth in investment in R\&D since 2003.
This growth is due to the increase in public health services of this country causing an expansion and innovation in the pharmaceutical sector of China. Airfinity. (2021), Wouters, O. J. et al. (2021) and Zhang, X., \& Nie, H. (2020).

\section{Conclusions}

Large-scale medicine manufacturing is a primary need to meet the basic needs of the world's population. However, few pharmaceutical companies in the world have the infrastructural and technological capacity for large-scale drug production, like it happens countries where the population's medical demand has led to pharmaceutical innovation. Fact that does not apply to developing countries, where the population is the most affected in the supply of safe and quality medicines.

Therefore, this study proposes using the similarity principle for the analysis and understanding of the behavior of the variables involved during the manufacture of oral dosage forms as a shorter way to scale-up process between two units to produce drugs on a large scale and with quality assurance to cover the health needs of the population.

\section{References}

Airfinity. (2021). Recuperado de https://www.airfinity.com/

Anaya, A. \& Pedroza, H. (2008). Escalamiento, el arte de la ingeniería química: Plantas piloto, el paso entre el huevo y la gallina. Tecnología, Ciencia, Educación, 23(1),31-39. ISSN: 01866036.

Faure, A., York, P., \& Rowe, R. C. (2001). Process control and scale-up of pharmaceutical wet granulation processes: a review. European Journal of Pharmaceutics and Biopharmaceutics, 52(3), 269-277. doi:10.1016/s09396411(01)00184-9

Fernández, C. (2019). Todo lo que hace la industria farmacéutica por mejorar nuestro planeta. LA VANGUARDIA. (23 de octubre del 2019). Recuperado de https://www.lavanguardia.com/vida/salud/2019 1023/471147188046/sostenibilidad-desarrolloindustria-farmaceutica-objetivos-brl.html 
Hernández, R., Fernández, C., \& Baptista, P. (2010). Metodología de la investigación. México: McGraw-Hill

Leuenberger, H., \& Betz, G. (2007). Chapter 15 Granulation process control - production of pharmaceutical granules: The classical batch concept and the problem of scale-up. Granulation, 705-733. doi:10.1016/s01673785(07)80050-9

Organización Mundial de la Salud [OMS]. (2020). Recuperado de https://www.who.int/

Poozesh, S. \& Bilgili, E. (2019). Scale-up of Pharmaceutical Spray Drying Using Scale-up Rules: A Review. International Journal of Pharmaceutics.

https://doi.org/10.1016/j.ijpharm.2019.03.047

Quiroga, R. (2020). Esperanza de vida en México creció a 76.6 años, informa la OMS. (13 de mayo del 2020). Recuperado de https://www.eleconomista.com.mx/arteseideas/ Esperanza-de-vida-en-Mexico-crecio-a-76.6anos-informa-la-OMS-20200513-0144.html

Raval, N., Tambe, V., Maheshwari, R., Deb, P. K., \& Tekade, R. K. (2018). Scale-Up Studies in Pharmaceutical Products Development. Dosage Form Design Considerations, 669700. doi:10.1016/b978-0-12-814423-7.00019-8 Su, Q., Ganesh, S., Moreno, M., Bommireddy, Y., Gonzalez, M., Reklaitis, G. V., \& Nagy, Z. K. (2019). A perspective on Quality-by-Control $(\mathrm{QbC})$ in pharmaceutical continuous manufacturing. Computers \& Chemical Engineering.

https://doi:10.1016/j.compchemeng.2019.03.00 1

Thapa, P., Tripathi, J., \& Jeong, S. H. (2019). Recent trends and future perspective of pharmaceutical wet granulation for better process understanding and product development. Powder Technology, 344, 864882.

https://doi.org/10.1016/j.powtec.2018.12.080
Vercruysse, J., Peeters, E., Fonteyne, M., Cappuyns, P., Delaet, U., Van Assche, I., De Beer, T., Remon, J. \& Vervaet, C. (2015). Use of a continuous twin screw granulation and drying system during formulation development and process optimization. European Journal of Pharmaceutics and Biopharmaceutics, 89, 239247. doi:10.1016/j.ejpb.2014.12.017

Wouters, O. J., Shadlen, K. C., Salcher-Konrad, M., Pollard, A. J., Larson, H. J., Teerawattananon, Y., \& Jit, M. (2021). Challenges in ensuring global access to COVID19 vaccines: production, affordability, allocation, and deployment. In The Lancet (Vol. 397, Issue 10278, pp. 1023-1034). Elsevier B.V. https://doi.org/10.1016/S0140-6736(21)003068

Zhang, X., \& Nie, H. (2020). Public health insurance and pharmaceutical innovation: Evidence from China. Journal of Development Economics, 102578 . doi:10.1016/j.jdeveco.2020.102578 